\title{
A SURPRISING DISCOVERY OF AMERICAN PIKA SITES IN THE NORTHWESTERN GREAT BASIN
}

\author{
Mackenzie R. Jeffress ${ }^{1}$, K. Jane Van Gunst ${ }^{2}$, and Constance I. Millar ${ }^{3}$
}

\begin{abstract}
Although the American pika (Ochotona princeps) continues to receive attention due to documented declines and range retractions, particularly in the Great Basin, thorough range inventories have yet to be completed in many parts of the region. Here we report on recently discovered populations in northwestern Nevada in areas not suspected to support pika activity under current climate regimes. We describe 238 new locations ("sites") with evidence of past or current occupancy by pikas which cluster into 31 locales, which we interpret as metapopulations or "demes," in 15 distinct mountain ranges or geographic areas. We documented twice as many relict sites (sites with evidence of former pika occupancy) as currently occupied sites, a result that supports previous observations of local range retraction and site losses within the pika's range. In the overall site data, median elevation and water year precipitation were higher and minimum and maximum July temperatures were lower for occupied sites than for relict sites. This pattern was repeated in most, but not all, of the 7 mountain ranges where both occupied and relict sites were found. Occupied sites were more likely to be found in areas with a narrow range of water year precipitation, in cooler climates, and on more mesic-facing aspects, but many of these environmental descriptors also describe relict sites. The apparent extirpation of pikas from the range with the highest elevation and lowest temperatures (Black Rock Range) and the continued persistence in some of the lowest and hottest areas of our survey (Home Camp Range) are particularly noteworthy. Since pikas were known from only a handful of early 20th century records in the area, these surveys greatly expand our understanding of both current and historic pika distributions in the northwestern Great Basin and shed light on patterns of pika persistence and extirpation in a region typified by harsher climates respective to other areas with extant pika populations. Furthermore, our results emphasize the importance of conducting spatially extensive fieldwork to better understand site extirpations and species range retractions.
\end{abstract}

RESUMEN.-Aunque la pica americana (Ochotona princeps) continúa recibiendo atención debido a su declive documentado y a su gama de retracciones, en particular en la Gran Cuenca (Great Basin), aún resta completar los inventarios sobre su rango de distribución en muchas partes de la región. Aquí reportamos poblaciones recientemente descubiertas en el noroeste de Nevada, en áreas en las que no se pensaba que las picas estuviesen activas bajo las condiciones climáticas actuales. Describimos 238 nuevos lugares (“sitios") con evidencia de ocupación pasada o actual de las picas que se agrupan en 31 sitios, los cuales interpretamos como metapoblaciones o "demes," en 15 montañas o áreas geográficas distintas. Documentamos el doble de sitios relicto (sitios que justifican la ocupación histórica de picas) que los sitios habitados actualmente; respaldando observaciones previas de retracción del rango local y la pérdida de sitios dentro del rango de las picas. $\mathrm{Al}$ observar los datos generales del lugar, tanto la elevación media como las precipitaciones anuales fueron más altas, y las temperaturas mínimas y máximas en julio fueron más bajas en los sitios habitados actualmente que en los sitios relicto. Este patrón se repitió en la mayoría, pero no en todos, de los siete sitios montañosos en donde se encontraron sitios ocupados y sitios relicto de pica. Los sitios ocupados fueron más propensos a encontrarse entre el límite inferior y el límite superior de precipitaciones anuales, en climas más fríos y en condiciones más mésicas, pero muchas de estas características ambientales también describen sitios relicto. Es particularmente significativa la aparente desaparición de las picas de las montañas con mayor elevación y con temperaturas más bajas (cordillera Black Rock), y su persistencia en algunas de las áreas más bajas y más cálidas de nuestra investigación (cordillera Home Camp). Dado que las picas sólo eran conocidas por unos cuantos registros pertenecientes a principios del siglo XX en el área, estos monitoreos amplían enormemente nuestra comprensión tanto de su distribución actual como de su distribución histórica en la Gran Cuenca del noroeste y clarifican sobre los patrones de persistencia y de desaparición de las picas en una región tipificada por climas más severos con respecto a otras áreas con poblaciones de pica. Además, nuestros resultados hacen hincapié en la importancia de llevar a cabo extensas investigaciones de campo para comprender mejor las desapariciones en ciertos sitios y las retracciones de estas especies.

American pikas (Ochotona princeps) are small mammals related to rabbits and are patchily distributed in broken rock landforms (e.g., talus and lava flows) of mountainous western North America (Smith and Weston 1990). Limits to thermoregulation combined with specific habitat requirements and metapopulation dynamics suggest that pikas

\footnotetext{
1Nevada Department of Wildlife, 60 Youth Center Road, Elko, NV 89801. E-mail: mrjeffress@ndow.org

${ }^{2}$ Nevada Department of Wildlife, 815 E. Fourth St., Winnemucca, NV 89445.

${ }^{3}$ USDA Forest Service, Pacific Southwest Research Station, Albany, CA 94710.
} 
could be vulnerable to climate change. For example, pikas appear to be in decline in some low-elevation locations of the Great Basin, and potential stressors, including decreased snowpack and warming summer months, are implicated in these declines (Beever et al. 2003, 2010, 2011). However, pikas continue to be found outside of described bioclimatic envelopes, and the species does not often fit well within species niche models (MartínezMeyer et al. 2004). Previously undocumented populations have recently been found in new areas, including lower-elevation, non-talus, and anthropogenic sites (Beever et al. 2008, Simpson 2009, Rodhouse et al. 2010, Collins and Bauman 2012, Millar et al. 2013, Varner and Dearing 2014a, Shinderman 2015). Furthermore, for several populations across the pika's range, species distribution models and projections that account for current and anticipated climate change and habitat connectivity suggest that the impacts on pikas will vary by place (Jeffress et al. 2013, Schwalm et al. 2016). Resilience also appears to relate to pikas' habitat dependence on broken rock landforms, which develop thermal regimes at least partially decoupled from surface temperatures and thereby mitigate seasonal temperature stresses on pikas (e.g., Varner and Dearing 2014b, Hall et al. 2016, Millar et al. 2016). Therefore, generalizations about pika extirpations at regional and species-wide scales might be inaccurate, and place-based assessments relying on extensive surveys over multiple years are needed (Jeffress et al. 2013).

Pikas are a Nevada Species of Conservation Priority and the Nevada Wildlife Action Plan calls for a thorough statewide inventory of the species (Wildlife Action Plan Team 2012). Though much of Nevada has been surveyed for pikas, little was known about pika distribution, potential connectivity among sites, and site characteristics of both currently occupied and seemingly relict sites across the northwestern portion of the Great Basin, making that region particularly important for conservation of the American pika. The area has recently documented extirpated sites, as well as newly discovered occupied sites. Early 1900s naturalist E.R. Hall (1946) captured pikas in the area of Barrel Springs (near the California border), near Summit Lake, and in the Pine Forest Mountains. However, resurveys of these sites, starting in the 1990s, have documented only old evidence of pikas, suggesting extirpation (Beever et al. 2011 [App. V], Millar et al. 2014). Conversely, Collins and Bauman (2012) documented newly discovered populations on the Sheldon National Wildlife Refuge (NWR), in areas just north and west of Hall's Summit Lake site and in nearby southern Oregon's Hart Mountains, and Beever et al. (2008) found a small extant population of pikas in Boulder Canyon in the Hays Canyon Range, Nevada (Fig. 1). Additionally, Millar et al. (2013) documented nearby populations to the west in northern Great Basin portions of California, above the Madeline Plain, and in the South Warner Mountains. Interestingly, Hall (1946) noted that pikas "are much more widely distributed in northwestern Nevada than our records indicate." Yet, aside from these few areas mentioned, this region has not been extensively surveyed until now. The northwestern portion of the Great Basin is atypical compared to the mountainous ("alpine") landscapes associated with much of the species' range. The area is at a lower elevation that is warmer and more xeric than expected given its latitude, providing an opportunity to understand how a species vulnerable to heat stress persists in a warmer and drier environment. Furthermore, the region is at the edge of the range for the Sierra Nevada subspecies (O. p. schisticeps; Hafner and Smith 2010). In the context of understanding climate change impacts, examining populations at the range periphery provides valuable insight into a species' adaptive potential, especially for species like pika, which are dispersal-limited habitat specialists, with lowered ability to avoid or adapt to changes in their environment (Thomas et al. 2001, Parmesan 2006, Morueta-Holme et al. 2010).

The goal of our study was to conduct a more complete and spatially extensive survey of potential pika habitat in northwestern Nevada to better understand the current and historic distribution in the area. Here, we document numerous pika sites over a 2-year survey period and present our results at multiple scales, from the smaller "site" level to a snapshot of potentially connected population centers (or "demes") to larger mountain ranges. At these scales, we describe climatic and environmental variables in multiple occupancy categories to provide insight into factors associated with pika persistence and extirpation within the region. Our hope is that our survey 


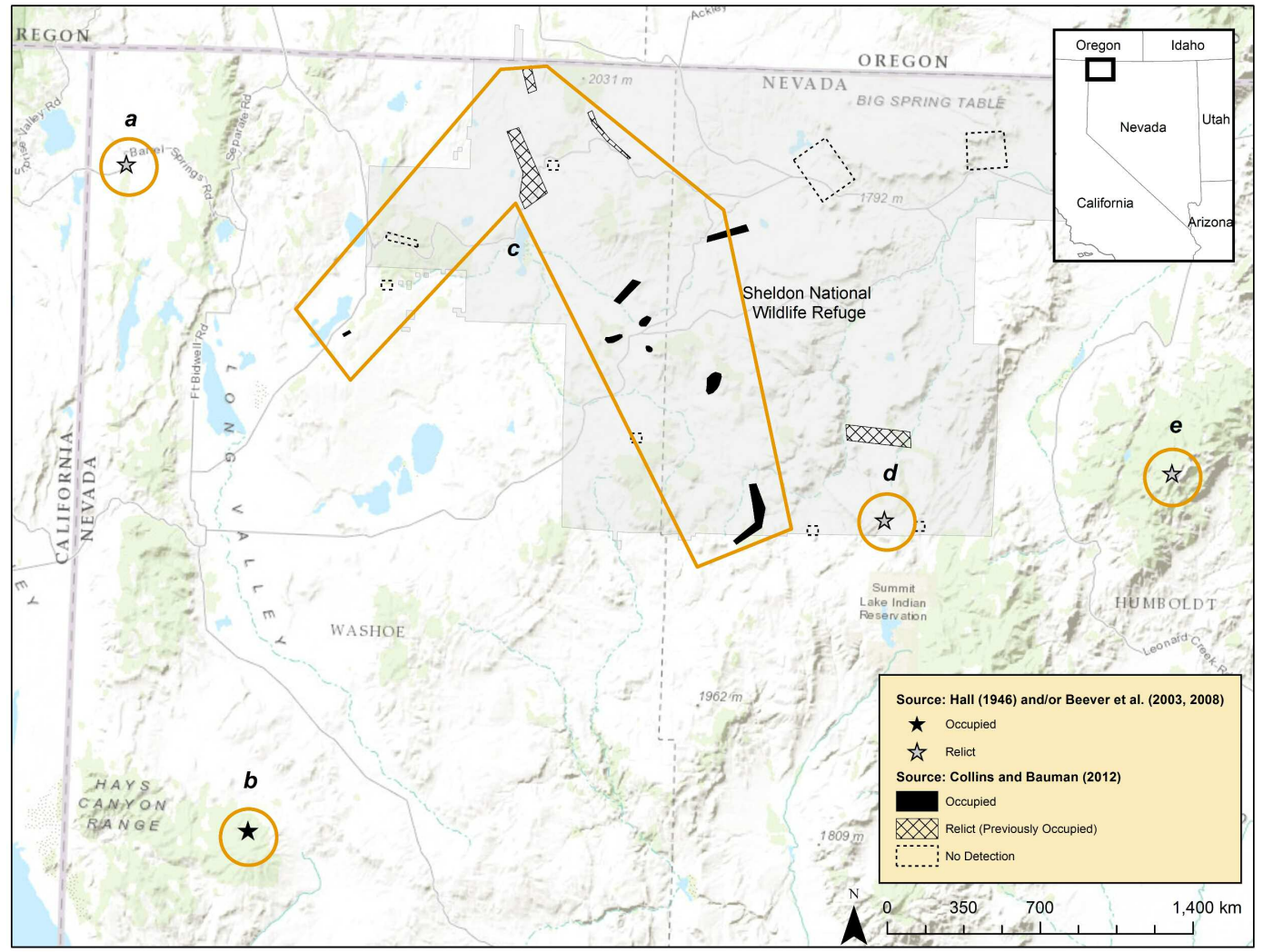

Fig. 1. Sites in northwestern Nevada documented prior to 2014 as American pika habitat (noted as occupied or relict at the time of observation): (a) Barrel Springs/Fort Bidwell, occupied in 1941 (Hall 1946) but since extirpated (i.e., relict; Beever et al. 2003); (b) Boulder Canyon in the Hays Canyon Range first documented as occupied in 2002 (Beever et al. 2008); (c) mix of occupied and recently extirpated sites, first documented in 2009, on and near the Sheldon National Wildlife Refuge (Collins and Bauman 2012); (d) N Summit Lake, occupied in 1936 (Hall 1946) but since extirpated (Beever et al. 2003); and (e) Duffer Peak in the Pine Forest, occupied in 1935 (Hall 1946) but since extirpated (Beever et al. 2003).

results and insights will refine characterizations of the pika's ecological niche and further a comprehensive understanding of population dynamics and associated conservation needs for American pikas in the Great Basin.

\section{Methods}

\section{Study Area}

Surveys were restricted to northwestern Nevada but the study area had no other preconceived boundaries; rather, areas were surveyed opportunistically, as access and the availability of personnel allowed. Mountain ranges surveyed included the Black Rock Range, Hays Canyon Range, Home Camp Range, Little High Rock Mountains, Massacre Range, Mosquito Mountains, Painted Point Range, and Nut Mountain, as well as upland regions that do not fall into named mountain ranges, such as the Crooks Lake Hills. These upland areas are part of the Black Rock Plateau and sites were dominated by basaltic rock. Upland vegetation primarily consisted of mountain big sagebrush (Artemisia tridentata vaseyana), Wyoming big sagebrush (Artemisia tridentata wyomingensis), and bitterbrush (Purshia tridentata), with a perennial grass and forb understory. Some of our sites also had western juniper (Juniperus occidentalis) and cheatgrass (Bromus tectorum) in the vicinity. All sites surveyed were on public land administered by the Department of the Interior Bureau of Land Management.

\section{Surveys}

We visited potentially suitable locations (i.e., talus, broken lava, and coarse rock matrix 
landforms) that had been identified via aerial imagery or preliminary ground inspection, and assessed these for pika presence in 2014 and 2015. We surveyed a single potential habitat patch for at least 30 person-minutes and documented evidence of current or past pika occurrence. We also noted when a site was surveyed but no evidence of pika presence was found. Survey sites and evidence encountered were often further documented by collecting pellets and taking photos. As pika sign tends to be clustered in small areas, we combined all detection records within 50 $m$ of each other into a single "site." Therefore, a site could contain one to several pika territories (Smith and Weston 1990) and could be considered representative of a habitat area or patch. To evaluate pika occurrence at a coarser scale, we combined detections that were within $3 \mathrm{~km}$ of each other (which is greater than the cited average maximum dispersal distance of $2 \mathrm{~km}$; Smith and Weston 1990) and called these clusters "demes" (as in Millar et al. 2013). These demes are meant to present a snapshot of potentially connected populations. Finally, we examined results by mountain ranges and distinct geographic areas defined by Charlet (unpublished data).

Occupied sites were identified by one or more detections of hay piles containing current year vegetation, pika calls, and pika sightings. Possibly occupied sites were identified by the detection of questionably fresh hay (limited green material) or fresh-appearing scat (green and perched but not abundant or associated with distinctly fresh hay). Relict sites were identified by one or more detections of hay pile remnants (brown and decomposing vegetation) and old scat (brown or moldy, dry, and no longer perched). Sites where only pika-like urine staining on rocks was found were described as possibly relict; however, there is currently no way to confirm these stains as pika-created. Areas surveyed that had neither current nor historic evidence of pika presence were also recorded, with coordinates taken at the center of the area searched and annotated at the same scales as described above. With this single-visit rapid assessment survey methodology, the potential for false negative results can be high, particularly when considering possible detectability issues (e.g., sites that might have had old sign that we were unable to locate or seasonal effects on detection). However, previous studies have found high detection probabilities $(\geq 0.90)$ using these survey methodologies (Beever et al. 2008, 2010, Rodhouse et al. 2010, Erb et al. 2011, Moyer-Horner et al. 2012, Ray et al. 2016), and given our use of multiple sources of conspicuous and persistent sign and trained observers, we used the detection of current pika presence to indicate that a site was occupied (as was done in Jeffress et al. 2013). This allowed us to focus our resources on increasing survey coverage. Nevertheless, we acknowledge that multiple surveys of an area are needed to confirm true extirpation or absence and encourage the classification of relict and no-detection sites to be interpreted with a level of prudence.

\section{Analysis}

To help describe our sites, we used several environmental variables (e.g., elevation, slope, and aspect) extracted from a 10-m Digital Elevation Model (DEM) and a 30-m pixel landform dataset that derived landform position classes based on (1) a refined and adjusted Topographic Relative Moisture Index (TRMI; accounting for slope position and angle, slope shape, and slope aspect), (2) landform position from valley flats to steep slopes, and (3) climatic zone stratification based on the Soil Adjusted Vegetation Index, a measure derived from remote sensing (see table 1 in Manis et al. [2001] for the slope limits and TRMI values that define each of the landform position classes). Aspect was binned into one of eight $45^{\circ}$ ordinal classes (e.g., NE, S, SW). We also calculated total daily solar radiation (both diffuse and direct) using the solar radiation tool in ArcMap (Fu and Rich 1999). The solar analyst tool uses aspect and slope from a 30-m DEM to derive a measure of clear-sky radiation over the single-day period of 15 August, thereby representing the total amount of insolation (indicating heat load from direct sunlight) and total solar irradiance during peak summer conditions (Fu and Rich 1999, 2002).

We present our results by occupancy status and at multiple scales including site, deme, and mountain range. In addition to the environmental variables, we examined several candidate climatic variables including maximum and minimum January temperature as a measure of wintertime stress and maximum and minimum July temperature as a measure 
of summertime stress (Beever et al. 2011, Wilkening et al. 2011). The 800-m PRISM normals from 1981 to 2010 (Daly et al. 2008) were used to derive temperature variables (as done in Schwalm et al. 2016). We derived average water year precipitation over the 1981-2010 period from gridded monthly PRISM precipitation data. Water year precipitation is widely used to describe climate and changes in climatic trends in the interior western United States, such as changes in snowpack, snowmelt, seasonal shifts in vegetation, and vegetation growing period (Regonda et al. 2005, Wilkening et al. 2011). Water precipitation is derived from the October through September period and captures both the season of high precipitation input (late fall to early spring), as well as dry periods (late spring to early fall).

Because many of these variables are highly correlated (e.g., elevation is highly correlated with precipitation and with winter and summer maximum temperatures), we restricted inclusion of variables to those that have Pearson's product-moment correlation scores between -0.7 and 0.7 . For example, for our analysis we only used the median maximum and minimum July temperature with the knowledge that these variables are highly correlated with analogous variables from January. We presented the results of the landform variable in order to describe the overall environmental context for these sites, and we included analysis of elevation due to its common use in other studies. However, neither landform nor elevation was used in our regression tree analyses because of their correlation with other environmental and climate variables. Because of the novel settings of many of these locations, it is unclear exactly how these variables influence pika occurrence and how that influence changes depending on differences in macro- and microsites, differences in the talus structure, and differences in pika population demographics. Nonetheless, we present these variables because they are important in explaining pika occurrence elsewhere and it seems clear that climatic stress is important in describing both pika occupancy and extirpation in many areas (Beever et al. 2003, Wilkening et al. 2011).

We used a classification tree derived in the $\mathrm{R}$ statistical program ( $\mathrm{R}$ Development Core Team 2016) using the "rpart" and "rattle" libraries to describe the hierarchical nature of the environmental variables and climate variables derived at our study sites. A classification tree is a type of machine-learning tool that makes hierarchical binary splits in a dataset based on a drop in deviance (De'ath and Fabricius 2000). We restricted the tree to those sites where definitive sign of current or historic pika occupancy was found. We used water year precipitation, both July temperature variables, solar radiation, and the binned aspect variable for this analysis. The tree was not pruned but several controls were used in fitting the tree. These controls were as follows: (1) 20 observations needed to exist before a split was attempted, (2) at least 10 observations needed to exist in any terminal node, and (3) each split needed to increase the overall fit by 0.05 (e.g., a complexity parameter). These limitations were imposed to ensure parsimony by identifying the most important splits in our dataset.

\section{RESULTS}

Surveys occurred in September 2014 and March through October 2015, with most 2015 surveys occurring in August or later. Raw detections of pikas totaled 977, and an additional 21 sites were surveyed for a minimum of 30 person-minutes, but no evidence of pikas was found. The raw detections were clustered into 238 sites, constituting 31 demes in 15 mountain ranges and distinct geographic areas (Fig. 2).

\section{Sites}

Fifty-six $(23.5 \%)$ of the sites were occupied, $12(5.0 \%)$ were possibly occupied, $117(49.2 \%)$ were relict, 32 were possibly relict (13.4\%), and $21(8.8 \%)$ had no detected evidence of pika occurrence. No currently occupied or possibly occupied sites fell within habitat predicted to be occupied by the GAP species distribution model (USGS Gap Analysis Program 2013). Over our study area, only the relict Black Rock Range sites fell within GAPpredicted occupied habitat $(n=4)$. Most sites were located on gently sloping ridges and hills, moderately moist steep slopes, and moderately dry slopes (Fig. 3). The highest percentage of occupied sites $(42.8 \%)$ were on moderately moist steep slopes, while the highest percentage of relict sites (36.7\%) were on moderately dry slopes and moderately moist steep slopes 


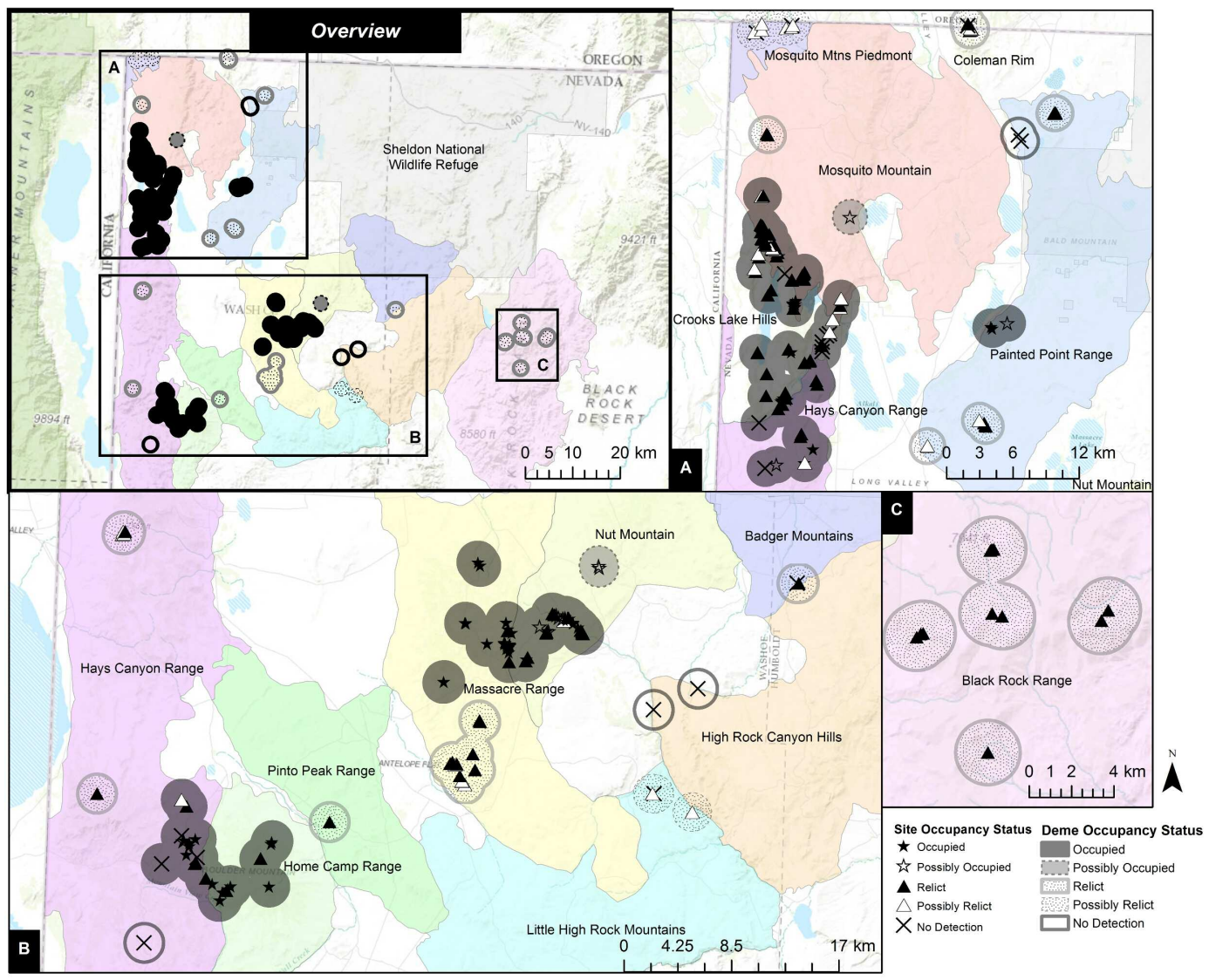

Fig. 2. Map of 2014-2015 pika survey sites and demes, indicated by occupancy status, and associated mountain ranges in northwestern Nevada. Panel A: The northwest portion of the study area including the Mosquito Mountains, Crooks Lake Hills, northern Hays Canyon Range, and Coleman and Massacre Rim. Panel B: The southwestern portion of the study area, from the Hays Canyon Range (furthest west) to the High Rock Canyon Hills and Badger Mountains (to the east). Panel C: The southeastern portion of the study area encompassing the Black Rock Range. A reference map for the panels is provided in the upper left and titled Overview.

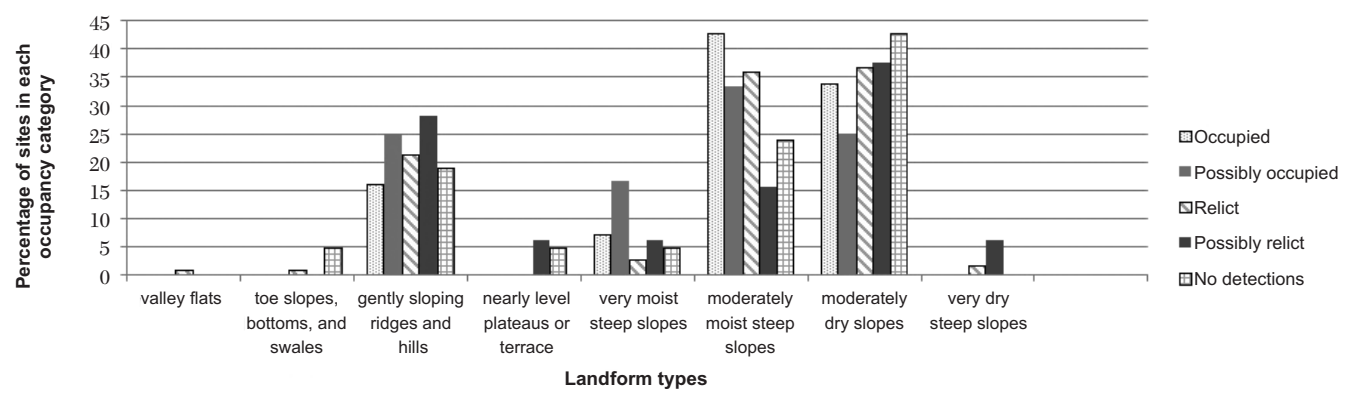

Fig 3. Percent of sites binned by American pika occupancy status and landform.

(35.9\%). We found relict-only sites on almost all landform types, while over $90 \%$ of occupied sites were found on 3 landform types characterized by moderate positions on either slope, moisture gradients, or both. Relict sites can be found in those places as well but they 


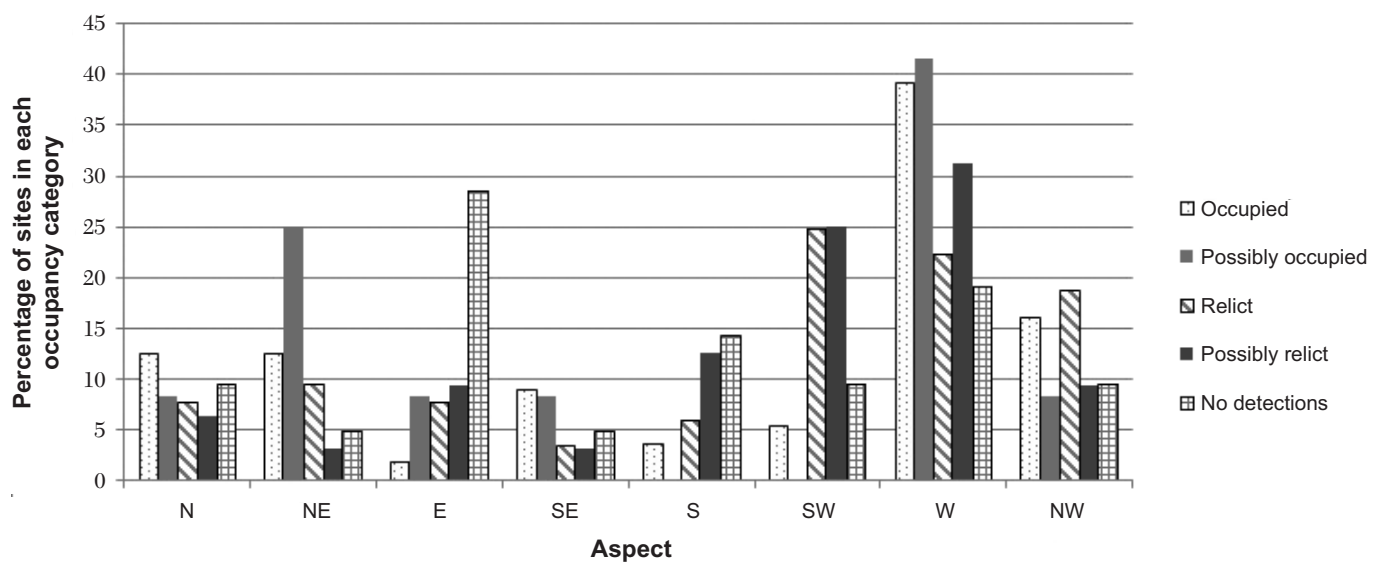

Fig 4. Number of sites binned by American pika occupancy status and aspect.

dominate the drier landform types. Thirty-nine percent of occupied sites were on west-facing slopes and $16 \%$ were on northwest-facing slopes (Fig. 4). Forty percent of currently occupied sites were distributed over northerly aspects (north- and northeast-facing together account for $25 \%$ ), and approximately $15 \%$ of occupied areas were found on south- and east-facing slopes. The highest percentage of relict sites were on southwest-facing slopes $(24.7 \%)$, followed by west-facing $(22.2 \%)$ and northwestfacing $(18.8 \%)$ slopes. However, occupied and relict sites were found throughout all aspect categories. Median elevation was highest for occupied sites $(1920 \mathrm{~m})$ and lowest for sites where no current or historic sign was detected $(1828 \mathrm{~m})$. Median elevation of definitively occupied sites was $29 \mathrm{~m}$ higher than that of relict sites.

Median water year precipitation was highest for occupied sites $(311.3 \mathrm{~mm})$ and lowest for possibly relict sites $(297.3 \mathrm{~mm})$. For relict sites, median water year precipitation was 14.2 $\mathrm{mm}$ less than for currently occupied sites; although, as with elevation, relict sites in the Black Rock Range had the highest water year precipitation of all sites in the survey region. Currently occupied sites had the lowest median maximum July temperature $\left(26.5^{\circ} \mathrm{C}\right)$ and lowest median minimum July temperature $\left(8.3^{\circ} \mathrm{C}\right)$ of all occupancy status categories in our survey area (Fig. 5). Sites without evidence of current or historic pika occupation were the warmest in our survey area, having the highest maximum July temperature $\left(27.0{ }^{\circ} \mathrm{C}\right)$ and highest minimum July temperature $\left(9.0^{\circ} \mathrm{C}\right)$.
Median maximum and minimum July temperatures of possibly occupied sites were about $0.2^{\circ} \mathrm{C}$ warmer than occupied sites. Outliers of both high and low temperatures were noted at several relict sites. Cold minimum July temperatures of $<7.1{ }^{\circ} \mathrm{C}$ were found at occupied and relict sites in the Home Camp Range and the Hays Canyon Range, at one occupied site in the Massacre Range, and at relict sites in the Black Rock Range. Some, but not all, of these sites were also colder as defined by a median maximum July temperature $<25.5{ }^{\circ} \mathrm{C}$. Three of the relict Black Rock Range sites were also the hottest sites of the survey area using minimum July temperature as the measure. Median total radiation was highest for sites where pika sign was not found $\left(7125\right.$ watt-hours $\left.[\mathrm{Wh}] / \mathrm{m}^{2}\right)$ and lowest for possibly occupied sites $\left(5076 \mathrm{Wh} / \mathrm{m}^{2}\right)$. Definitively occupied sites received much more solar radiation $\left(\right.$ median $=6927 \mathrm{Wh} / \mathrm{m}^{2}$ ) than relict sites $\left(\right.$ median $\left.=6138 \mathrm{Wh} / \mathrm{m}^{2}\right)$.

Demes and Mountain Ranges

Eight $(25.8 \%)$ of the demes were occupied, $2(6.5 \%)$ were possibly occupied, $14(45.2 \%)$ were relict, $3(9.7 \%)$ were possibly relict, and $4(12.9 \%)$ had no detected evidence of pika occurrence. Overall, the occupied demes were found more in the western part of our study area (Fig. 2). Five demes contained only one site $\left(7.3 \mathrm{~km}^{2}\right)$, whereas the largest deme (Carter Reservoir, $74.0 \mathrm{~km}^{2}$ ) contained 32 sites, was occupied, and was in close proximity to 2 other occupied demes. Our results indicate 4 population centers in our survey region: 

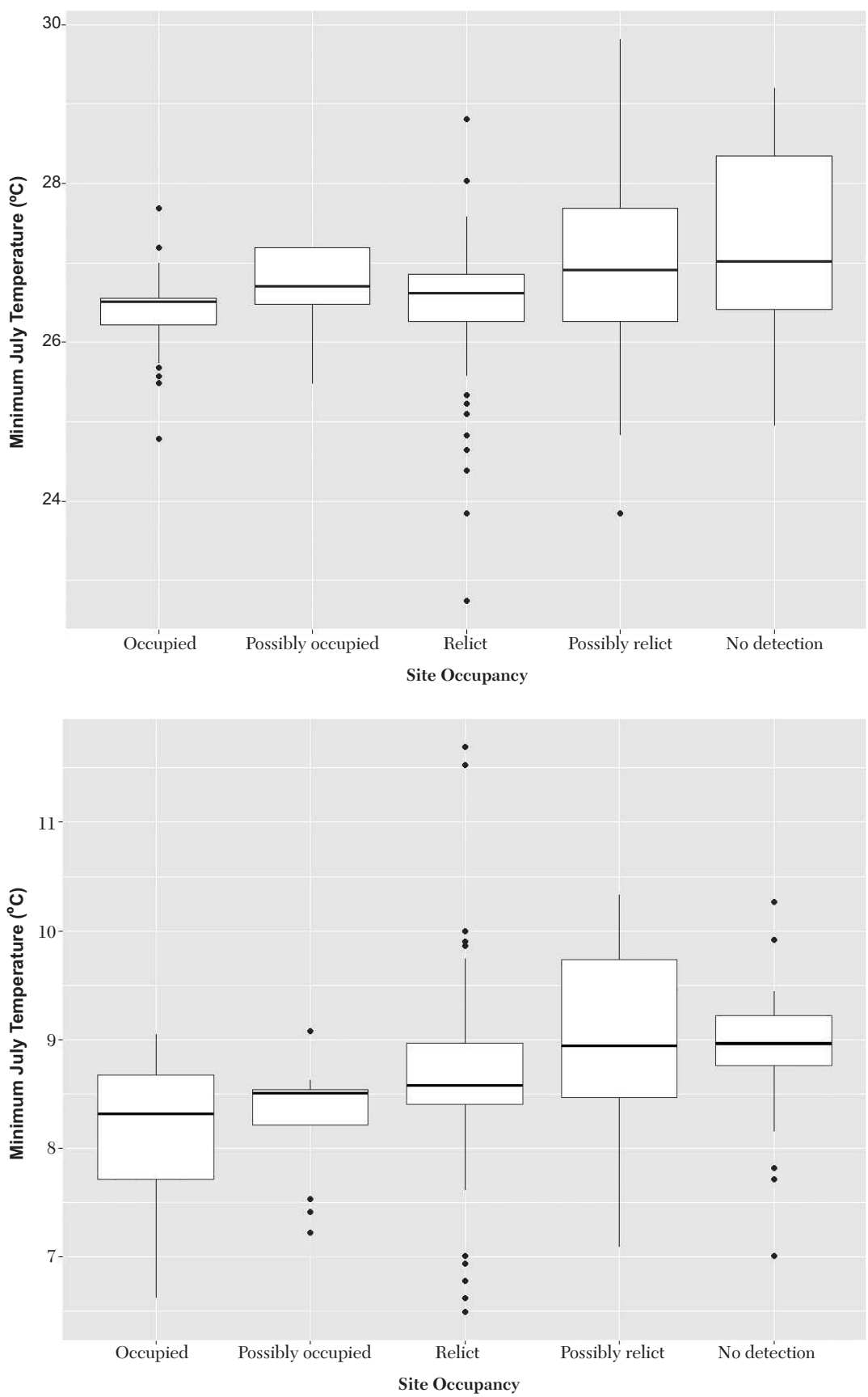

Fig. 5. Boxplots of median maximum (top) and minimum (bottom) July temperature by site occupancy status.

(1) Crooks Lake, Carter Reservoir, and Southern Vya Rim (Fig. 6) demes (96 sites, 16.7\% occupied), (2) Boulder Canyon and southern Hays Canyon demes (24 sites, $54.2 \%$ occupied), (3) Massacre Ranch and Grassy Canyon
(Fig. 7), and Nut Mountain demes (45 sites, $56.8 \%$ occupied), and (4) the Massacre Rim deme (Fig. 8; 3 sites, $66.7 \%$ occupied).

Although we attempted to survey as much of the study area as possible, we cannot go 


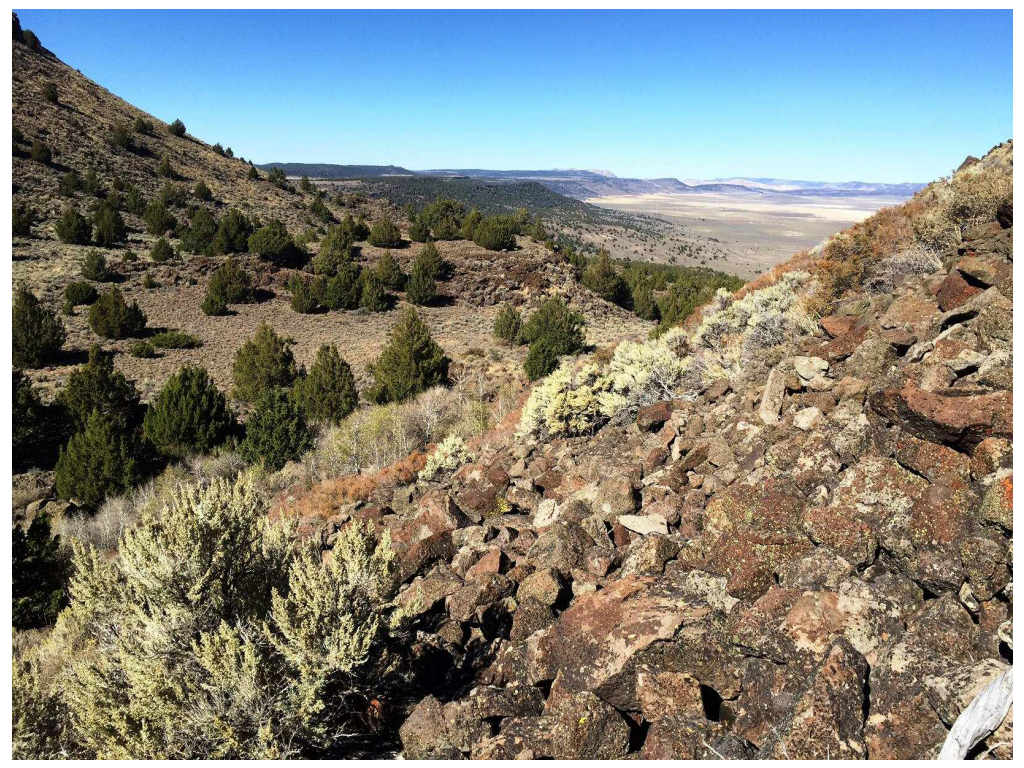

Fig. 6. Vya Rim looking toward the Carter Reservoir deme, which includes the Mosquito Rim area. The broken rimrock in these demes contains a mix of occupied and relict sites. The habitat is sagebrush-steppe and scattered western juniper, and the view is north. This site had many hay piles and fresh scat and was one of the most densly occupied sites that we visited.

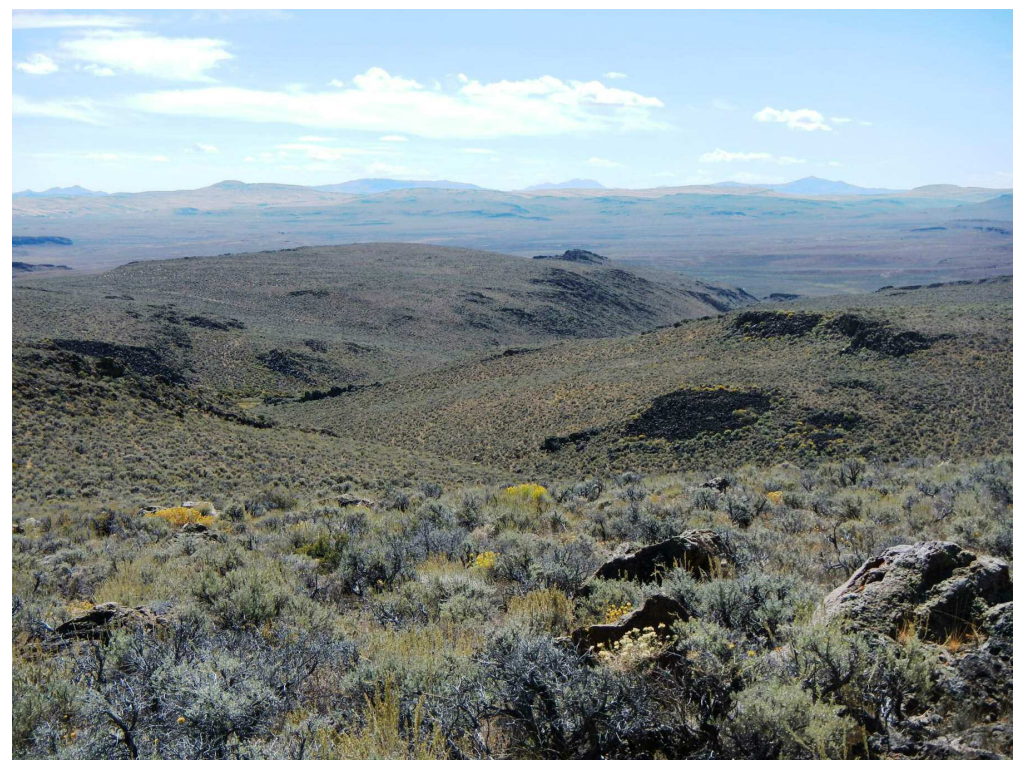

Fig 7. The Grassy Canyon deme in the Massacre Range. Several patches of pika-occupied basalt outcrops are visible here and continue down into the canyon. Sagebrush steppe dominates the deme, and the view here is to the southwest.

beyond speculation about the potential for habitat and connectivity across unsurveyed areas. Our surveys indicate that the extant Boulder Canyon and Grassy Canyon demes may once have been connected via the Pinto Peak deme, but this area is now likely extirpated. It is also possible that the Boulder Canyon deme was once connected throughout 


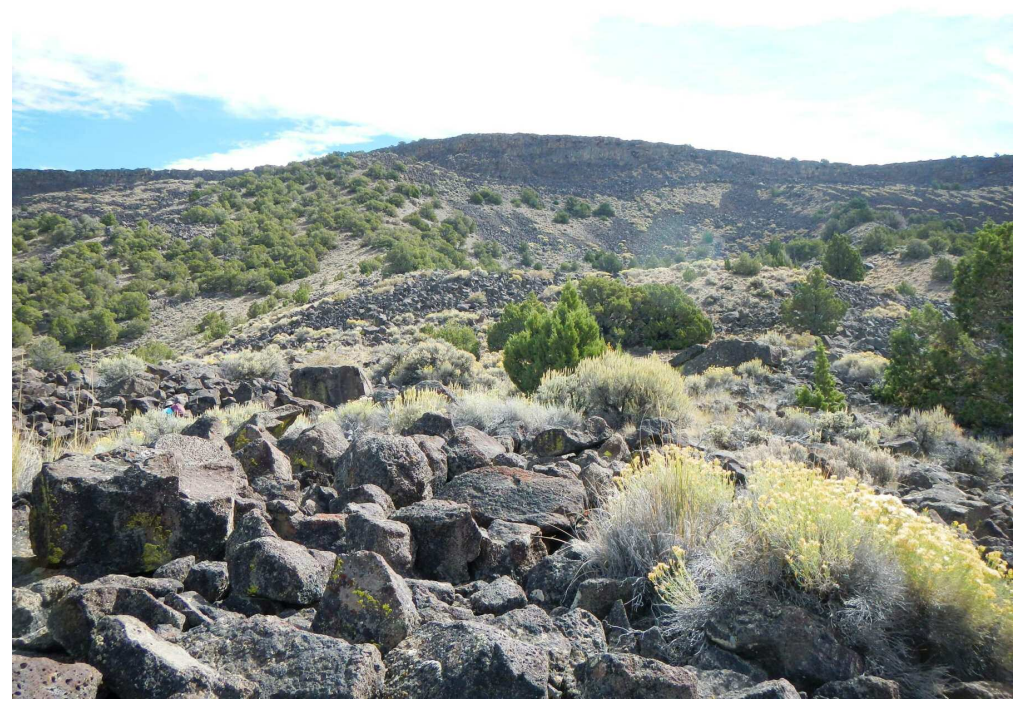

Fig. 8. The Massacre Rim deme in the Painted Point Range. This area was occupied throughout, and although not extensively surveyed as part of this study, the rim has similar and likely connected habitat for several miles to the north and south.

the Hays Canyon Range north to the Carter Reservoir deme, but surveys that documented relict demes inbetween, such as at Forty-niner Mountain, suggest another possible and recent break in connectivity. The Massacre Rim deme is likely much larger than the area we were able to document due to limited survey time (see Fig. 8 for photo of habitat that is representative of unsurveyed rim areas to north and south), but our results do indicate that the Massacre Rim Wilderness Study Area to the southeast of the rim is now likely extirpated. The potential for connectivity of these demes to the previously documented Sheldon sites (Collins and Bauman 2012, Castillo et al. 2016) needs further exploration. Furthermore, the relict Black Rock demes (Fig. 9) were likely at one point connected to each other and possibly to the early 20th century-occupied Pine Forest Range to the north and the currently occupied Sheldon NWR to the west.

Our surveys covered 15 mountain ranges and distinct geographic areas in northwestern Nevada, 8 of which had $\geq 10$ survey sites per range. We found definitive sign of relict or current occupation in 11 of these ranges, with no conclusive evidence of historic occupation in the remaining 4 ranges (i.e., Badger Mountains, Little High Rock Mountains, Mosquito
Mountains Piedmont North, and the Yellow Hills). Only 7 of the 11 ranges had sites with current occupation, and in only 2 of those ranges, the Home Camp Range and Massacre Range, more sites with current occupation were found than relict sites. To examine differences between occupied and relict sites, we summarize elevation and maximum July temperature in these 7 ranges.

Sites in the Black Rock Range and on Little Hat Mountain in the Hays Canyon Range were the highest-elevation survey sites, and only historical evidence was found at these sites (Fig. 10). Median elevation of occupied sites was higher than that of relict sites in 3 of the 7 ranges and was roughly equal between the 2 occupancy categories in the Hays Canyon Range. In 3 of the 7 ranges (Home Camp Range, Massacre Range, and Painted Point Range), median elevation of relict sites was higher than that of occupied sites. The Home Camp Range had the lowest median elevation and Painted Point the second lowest of the 7 ranges; here, pikas were more likely to be found at the lower elevational limits (but see comments below about potential confounding survey effort in the Painted Point Range). In the Hays Canyon Range, the highest median elevation in our study area, median 


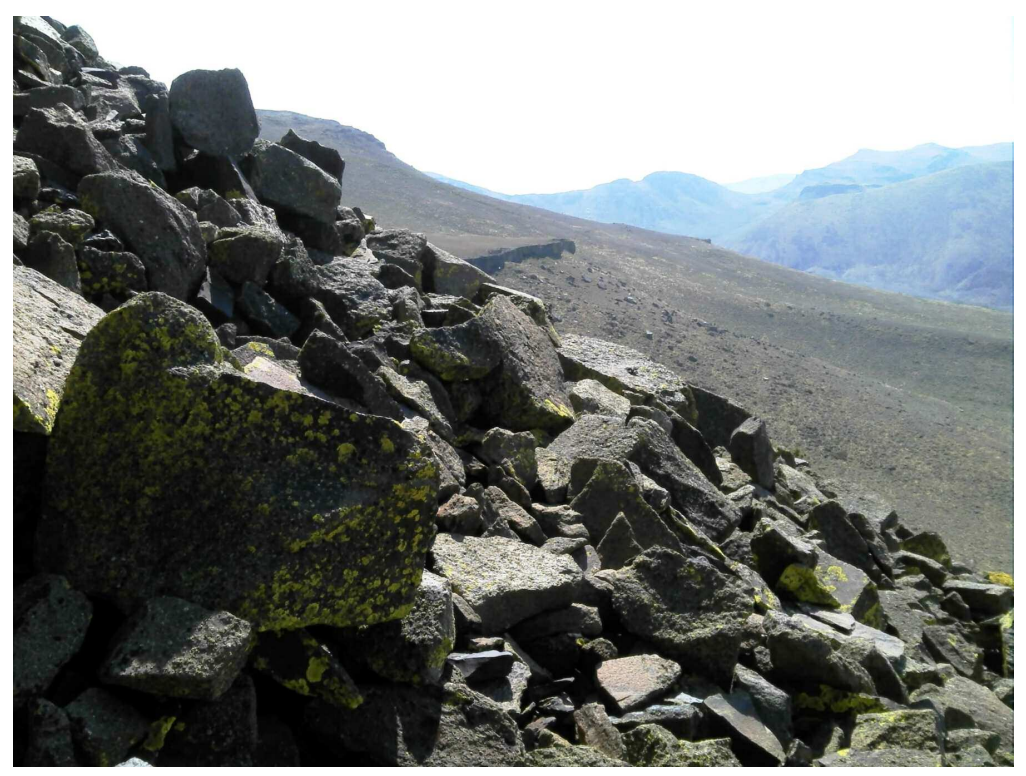

Fig. 9. A deme in the Black Rock Range. Although this was one of the highest elevation areas surveyed, only relict sites were documented in the demes throughout the range. The view is to the south toward the Colman River drainage.
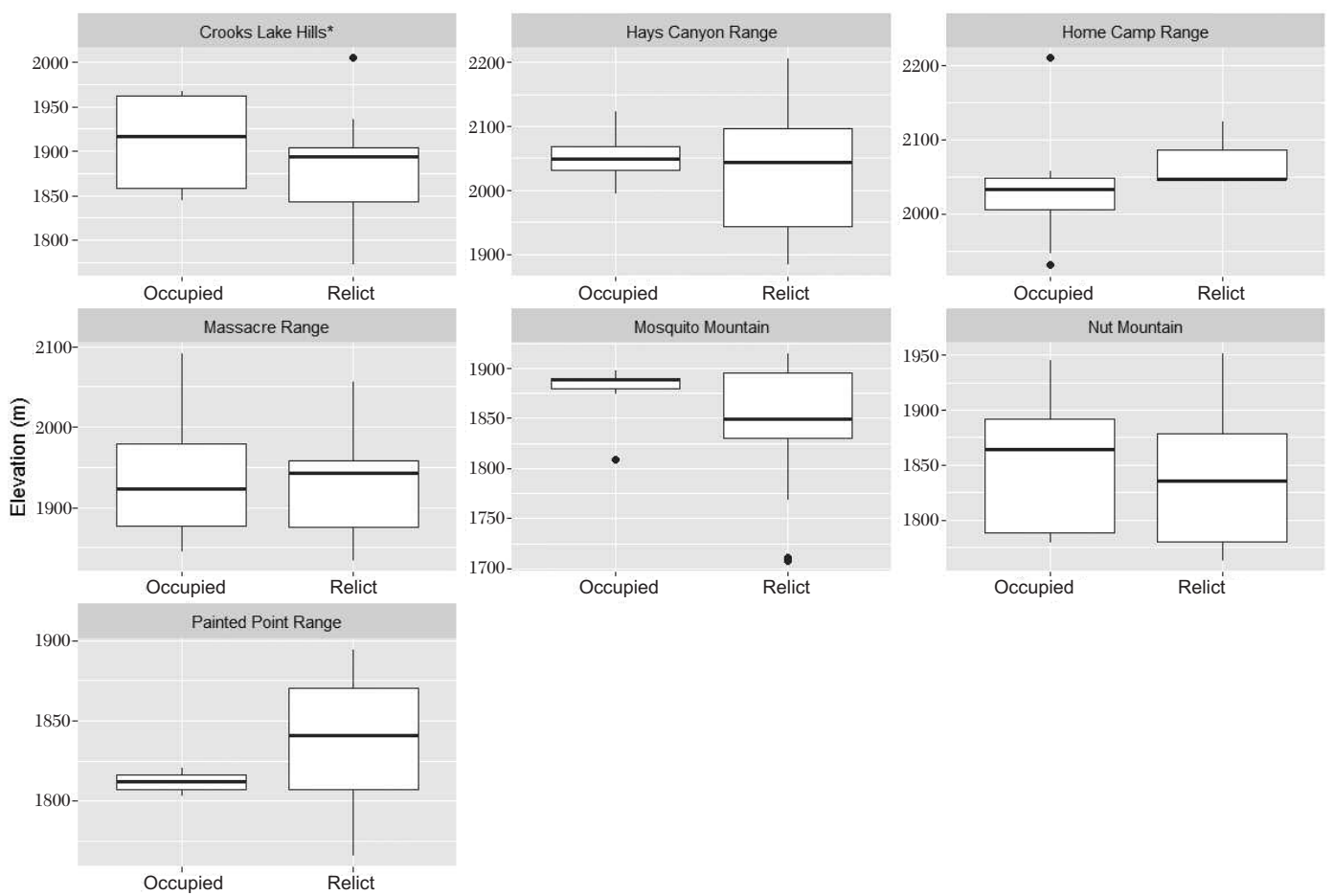

Site Occupancy

Fig. 10. Elevational boxplots for the 7 ranges (Crooks Lake Hills, Hays Canyon Range, Home Camp Range, Massacre Range, Mosquito Mountain, Nut Mountain, and Painted Point Range) where both occupied and relict sites were detected. 


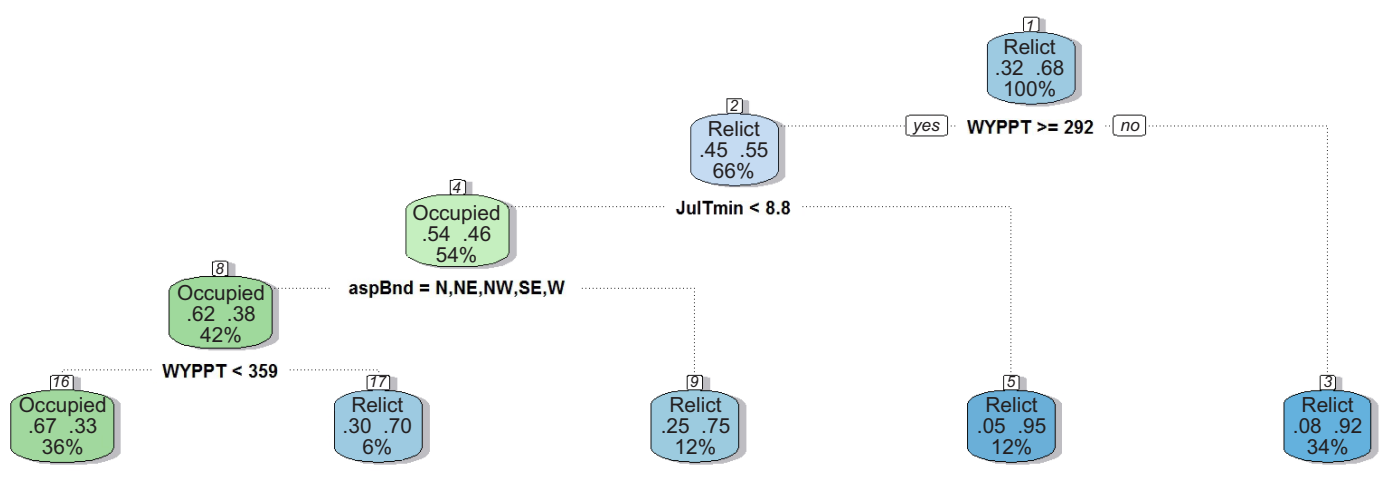

Fig. 11. The classification tree for the variables examined for all the occupied and relict sites in the dataset $(n=173$; WYPPT $=$ average water year precipitation $[\mathrm{mm}]$, aspBnd $=$ aspect, JulyTmin $=$ median minimum July temperature $\left.\left[{ }^{\circ} \mathrm{C}\right]\right)$. The tree can be read as a series of hierarchical characteristics resulting in a terminal node or leaf. Leaves show the designation of each site (either "occupied" or "relict") and the probability of membership in each class, with "occupied" as the first class (on the left) and "relict" as the second class (on the right). Lastly, each leaf presents the percentage of total observations used in each "branch." For example, when water year precipitation is under $292 \mathrm{~mm}$, then there is a $92 \%$ probability that the sites are relict and an $8 \%$ probability that the sites are occupied. There are 59 observations (34\% of 173) falling into this leaf.

elevation of occupied sites was just slightly higher than that of relict sites.

Occupied sites had higher median July temperatures in the Home Camp Range and Painted Point Range than relict sites. For all other ranges, occupied sites were cooler and characterized by lower maximum July temperatures than relict sites. At Massacre Range, although occupied sites tended to be at lower elevations than relict sites, they were often in cooler microsites. The same pattern was reflected in the minimum July temperatures. Regardless of whether occupied sites trend warmer or cooler than relict sites, differences in median temperature (both July minimum and maximum) between occupied and relict sites is $<1{ }^{\circ} \mathrm{C}$ in almost all cases (with minimum July temperature in the Hays Canyon Range being the exception). Our results could be due to an inability of the large 800-m PRISM cell size to accurately reflect conditions in small patches, or it could suggest that minor yet persistent temperature differences are important in site suitability for pikas. In the 2 ranges (Home Camp and Painted Point) that had the lowest median elevation and that were the hottest ranges in our study region, occupied sites were more likely to be found at the lower and hotter parts of the range. However, the pika population on Painted Point covers Massacre Rim, a large area that we suspect was occupied over a greater extent than where we surveyed.
Because of this area's close proximity to the Sheldon NWR and observations made nearby by other researchers (Collins and Bauman 2012, Castillo et al. 2016), we did not survey this likely extensive population; thus, results presented for this range may change when the area is surveyed more fully. Despite its relatively lower elevation and hotter climates, the Home Camp Range received the highest median precipitation, which may mitigate the relatively warm and lower-elevation environment. The Painted Point Range had the third highest median precipitation in the study area.

\section{Classification Tree Analysis}

The classification tree shows a series of "checks and balances," with environmental and climatic variables mitigating potentially harsh overarching conditions (e.g., a site with low precipitation will have a higher chance of remaining occupied if temperatures are cool). Variable "importance," a measure of predictive power of each variable, was ranked in the following order: water year precipitation, followed closely by minimum July temperature, maximum July temperature, binned aspect categories, and solar radiation (Fig. 11). The occupied sites were characterized by wet (water year precipitation over $292 \mathrm{~mm}$ ) and cold (minimum July temperature under $8.8^{\circ} \mathrm{C}$ ) climates and were mostly located on aspects not southerly or easterly. 


\section{Discussion}

Survey results presented here make evident that pika range and distribution in northwestern Nevada have changed dramatically in the 20 th and into the early 21 st centuries, with $<30 \%$ of survey sites showing signs of current pika persistence. Localized extirpations are evident on the western side of the range at high-elevation sites such as Little Hat Mountain and Forty-Niner Mountain and on the eastern side of the range throughout the highelevation Black Rock Range. To the north, many sites in the Crooks Lake Hills and Mosquito Mountains appear extirpated, and the Barrel Springs area (previously described as extirpated by Beever et al. 2003, 2008, Wilkening et al. 2011, Millar et al. 2014) remains extirpated. Despite these range retractions and calls for more spatially extensive fieldwork (Beever et al. 2008), we note several previously undocumented extant populations in a region formerly described as containing only extirpated sites outside of the extant Massacre Rim, Sheldon NWR, and Boulder Canyon (Hays Canyon Range) populations (Beever et al. 2003, 2008, Wilkening et al. 2011).

Similar to recent pika inventories on the Sheldon National Wildlife Refuge (Collins and Bauman 2012), all of our currently occupied and most (all but 2) of our relict sites were below the 2500-m "threshold" considered typical for pikas in the western Great Basin (Smith 1974, Smith and Weston 1990, Millar et al. 2013), although we note that our sites are near the northern portion of the region and some latitudinal depression would be expected. When landform is considered, pikas in our study are generally occupying more moderate areas, perhaps indicative of the "goldilocks effect" (not too hot, not too cold) where environmental position (i.e., aspect, slope, and elevation) and local climate (i.e., precipitation and temperature) create a more hospitable and less variable environment. Unlike the more typical patterns in places such as Crooks Lake Hills, Mosquito Mountain, and Nut Mountain, many other areas in northwestern Nevada do not fit the traditional pattern where elevation is lower and heat stress is higher at relict sites than at occupied sites. In ranges such as Hays Canyon, Home Camp, and Massacre, occupied sites trend lower and hotter than relict sites. Despite these atypical associations, pikas in the Home Camp Range appeared to be the most connected and largest population documented in our survey area.

Pikas are hypothesized to be affected in many ways by decreased precipitation input and loss of snowpack, including reduced available forage due to lowered vegetation productivity, increased spread of disease, loss of insulating cover, and exposure to more extreme cold temperatures (Wilkening et al. 2011). Our study did not measure precipitation changes over time in relation to changing occupancy over time. We report here only the differences in water year precipitation amounts across sites overall and across sites within a range. Thus, we cannot comment on how precipitation changes have driven changes in occupancy, especially since we do not know exactly when sites became extirpated. However, we do note that in 2 mountain ranges where pikas are persisting at lower elevations (Painted Point and Home Camp), precipitation input over the survey areas within the ranges is among the highest in our study, suggesting that there could be some ameliorating influence of precipitation and the corresponding vegetation response in warmer areas. Places that received the highest amounts of precipitation (e.g., Black Rock Range, upper elevations of Home Camp Range, and Hays Canyon Range) appear extirpated, and because of this trend, the classification tree does place occupied sites below a maximum precipitation threshold. The degree to which this threshold is actually representative of a true limitation for pikas is unclear, particularly because we suspect that some type of stochastic event, such as fire or a disease outbreak (likely common in pika populations; Wilkening et al. 2011), and resulting fragmentation, prompted the loss of pikas in these areas.

The inconsistency of modeled climate factors in explaining occupied versus relict sites in our analyses might relate to the unique conditions of pikas' talus habitat and the scale at which variables were examined. For example, whereas weather station and modeled data such as PRISM provide information about surface free-air conditions, talus and related broken-rock landforms are widely known to have thermal regimes that are decoupled from external surface air (Harris and Pederson 1998, Sawada et al. 2003, Gude et al. 2003, Delaloye and Lambiel 2005, Zacharda et al. 
2007, Millar et al. 2014). Decoupling of talus from free-air circulation offers potential clues to the ability of pikas to persist under synoptic and regional climates that would appear unsuitable for them (Millar et al. 2016). Lava flows and other volcanic taluses, such as those found in our study area, are known to have particularly cold matrices with highly attenuated diurnal temperatures and often sustain persistent embedded ice that may provide beneficial daily and seasonal refuges for pikas (Millar et al. 2016, Ray et al. 2016, Smith et al. 2016). Decoupling processes may be responsible for our solar radiation finding, where mean solar radiation is higher at occupied than at relict sites. Higher solar radiation may indicate increased potential for vegetation growth at mid- and upper-elevation sites where pikas are found, while the ameliorating influence of the belowground structure allows pikas to remain in these sites. Vegetation growth within and around the talus may also moderate surface temperatures, and solar radiation may interact with temperature, precipitation, subsurface structures, and vegetation at each site to create beneficial conditions such as increased herbaceous vegetation and increased access to food through more frequent and earlier snowmelt. Unfortunately, our study has no data regarding the temperatures within the talus matrices, as might be collected with data-logging sensors, but future work in the area would benefit from these and other microsite data.

A myriad of factors govern patch occupancy dynamics, including connectivity to source patches, the amount of suitable habitat in an area, macro- and microclimate and the link between the two as mediated by the aboveand belowground talus structure, vegetation surrounding the patch, landscape variables that influence connectivity, source-sink dynamics, competition, predation, and disease, as well as the lag effects of many of these factors. As pikas are a classic example for metapopulation biology and source-sink dynamics (Kreuzer and Huntly 2003), it is possible that some site "extirpations" may only be temporary and sites might be recolonized after some time. However, we suspect that numerous relict sites documented across entire ranges (e.g., Black Rock Range) or areas within large portions of each range (e.g., Hays Canyon Range and northern High Rock Range) are true extirpations. Although the cause(s) may never be known, potential reasons for extirpation in some of these areas include loss of connectivity, small patch size (Stewart and Wright 2012), or impacts of stochastic events (e.g., disease). In other cases, it seems local climates may have become unsuitable either over space (at relatively lower elevations within or at the far edge of a local distribution) or over time. For example, some of the sites we found appeared to have been recently extirpated, such as in the Upper High Rock Canyon and the Hanging Rock Canyon in the High Rock Range. In other areas (e.g., Nellie Springs Mountain), the few extant sites we found may be vestiges of more abundant and widespread populations. Outside of these peripheral areas, we find currently occupied sites in spatially clustered areas where climate and connectivity appear conducive to maintaining pika populations in the long-term. Although Massacre Rim in the Painted Point Range was not thoroughly surveyed, we suspect pikas are dense and abundant across the entirety of the almost 7-km face, which possibly serves as a "mainland habitat" in the region. Techniques such as radiocarbon dating of scat samples from relict sites (as done in Millar et al. 2014) could provide insight regarding the pattern and causes of extirpations. For instance, considering that the Black Rock Range has burned in the last century, relating relict site ages as obtained from radiocarbon dating to fire history could help us better understand the influence of fire on pikas in more xeric, low-elevation sites. Radiocarbon dating might also indicate the direction of local range retractions, which could consequently be used to predict highpriority conservation areas and areas of possible future retractions or (re)colonizations.

In our surveys, we found relict sites that we expected to be occupied (e.g., Black Rock Range and the upper elevations of the Hays Canyon Range) and occupied sites where we did not expect pikas to currently exist (e.g., Home Camp Range and the lower elevations of the Hays Canyon Range) based on typical niche descriptions. In our study area, no single variable distinguished currently occupied sites from relict sites in the same manner across the mountain ranges, and the concept that current and historic pika distributions are contingent on particular combinations of local site characteristics, regional climate regimes, 
historical context, and connectivity ("idiosyncrasies of place”; Jeffress et al. 2013) is repeated in our work. Our results provide further evidence of the seemingly weak predictive power of thermal indices alone in many of these low-elevation and warm mountain ranges of northwestern Nevada. For example, the classification tree describes unique environmental settings that appear to foster persistence or extirpation. In the tree, the probability of a site being occupied ranged from $54 \%$ to $67 \%$ but the probability of a site being relict ranged from $55 \%$ to $95 \%$, indicating (1) a much higher predictive power with the variables used in pinpointing relict sites on the landscape, (2) significant overlap in environmental settings conducive to co-occurrence of both occupied and relict sites, and (3) the lack of additional predictive variables needed to discriminate occupied and relict sites in this study. When linked to environmental and climate variables, new analysis techniques, such as measuring stress hormones in individuals (Wilkening and Ray 2016), might provide additional insight into pika survival and factors influencing pika persistence. Furthermore, pika presence at a site does not necessarily mean the site has suitable habitat conditions that will allow for long-term pika persistence (Kreuzer and Huntly 2003). To more fully untangle why and how some populations persist and others do not, a more comprehensive approach beyond occupancy surveys alone will be needed.

Similar to Millar et al. (2013), we noted that previous studies often do not examine multiple scales of pika occupancy, which we attempted to address. Delineation of possible demes in our survey area provided insight into the potential for connectivity and allowed a better understanding of the importance of a "patch"-sized scale in determining area occupancy. We acknowledge that because we were unable to survey all potential habitat in every area, not every currently occupied and relict site was detected in our survey effort, and this lack of data may artificially cause some demes to appear disjunct. However, our approach was a significant improvement on previous studies that relied on a survey of only one site or one habitat patch. For example, if we relied on survey results from only our first 1 or 2 sites, our understanding of the occupancy of the area would have been very different, and we might have concluded that the area was recently extirpated when nearby patches were actually currently occupied.

Understanding pika population stressors may be particularly important to Bureau of Land Management managers in northwestern Nevada, where some districts include the American pika on sensitive species lists that are considered in decisions regarding land management activities and others do not (possibly because they were not even aware the species occurred in their district until now!). Beever et al. (2003) reported a higher probability of pika presence in places without livestock activity and in wilderness areas, and Millar (2011) discussed how grazing might be a factor influencing population conditions and status of pikas in the eastern Sierra Nevada and Great Basin. Many of our sites in the Crooks Lake Hills, Carter Reservoir, Mountain View drainage to the west of Boulder Canyon, and Grassy Canyon had active livestock grazing as well as a feral horse presence but, due to difficulty in quantifying, we were unable to include these variables and others, such as the presence of invasive plants (e.g., cheatgrass), in our current analysis. In spite of this, our study and future studies can help inform land management decisions and may guide proactive management opportunities to potentially improve connectivity, such as providing artificial talus corridors or considering assisted migration (Hobbs et al. 2010, Morueta-Holme et al. 2010, Wilkening et al. 2015).

Our surveys reveal new populations across northwest Nevada in several hotter and drier places than have been described for the American pika. Because of their isolated nature and relatively harsh conditions, these sites merit a long-term and robust monitoring program to address both population loss at currently occupied sites and possible recolonization of seemingly extirpated sites. Regional patterns in pika persistence and several seemingly imperiled populations underscore the need for more thorough inventory and monitoring programs that examine not just occupancy at a single site but also incorporate a more comprehensive regional understanding of connectivity and population dynamics at larger scales. The need for such work is urgent, given that we found twice as many relict sites as occupied sites in this region, with that ratio exaggerated in places like the Crooks Lake Hills. 
Many questions remain, most urgently ones surrounding connectivity, habitat patch size relative to connectivity, population trends, and protection and conservation measures for extant pika populations, such as those that exist in Home Camp Range, Painted Point Range, Nut Mountain, and Crooks Lake Hills. Consequently, we hope that this study is the first of many in the region.

\section{ACKNOWLEDGMENTS}

We especially thank Mark Enders, Rory Lamp, and Christy Klinger from the Nevada Department of Wildlife (NDOW) for their help with surveys across the study region. We thank Kenny Pirkle, Brad Bauman, and Cody Byrne from NDOW and Erik Beever with the U.S. Geological Survey for their knowledge and recommendations regarding survey areas. Gail Collins shared shapefiles for the Sheldon NWR, and Tom Dilts helped with the PRISM data compilation and derivation. We thank Elias Flores and staff at the Applegate Bureau of Land Management field office for insight and assistance with surveys on Massacre Rim. The NDOW provided the majority of the support for biologist field time and equipment, and the primary funding source was the State Wildlife Grants Program.

\section{Literature Cited}

Beever, E.A., P.F. Brussard, and J. Berger. 2003. Patterns of apparent extirpation among isolated populations of pikas (Ochotona princeps) in the Great Basin. Journal of Mammalogy 84:37-54.

Beever, E.A., C. Ray, P.W. Mote, and J.L. Wilkening. 2010. Testing alternative models of climate-mediated extirpations. Ecological Applications 20:164-178.

Beever, E.A., C. Ray, J.L. Wilkening, P.F. Brussard, AND P.W. MоTE. 2011. Contemporary climate change alters the pace and drivers of extinction. Global Change Biology 17:2054-2070.

Beever, E.A., J.L. Wilkening, D.E. McIvor, S.S. Weber, AND P.F. BRussaRD. 2008. American pikas (Ochotona princeps) in northwestern Nevada: a newly discovered population at a low-elevation site. Western North American Naturalist 68:8-14.

Castillo, J.A., C.W. Epps, M.R. Jeffreess, C. Ray, T.J. Rodhouse, and D. Schwalm. 2016. Replicated landscape genetic and network analyses reveal wide variation in functional connectivity for American pikas. Ecological Applications 26:1660-1676.

CharLet, D. Unpublished data. Nevada physiography: a sketch.

Collins, G.H., and B.T. Bauman. 2012. Distribution of low-elevation American pika populations in the northern Great Basin. Journal of Fish and Wildlife Management 3:311-318.
Daly, C., M. Halbleib, J.I. Smith, W.P. Gibson, M.K. Doggett, G.H. Taylor, J. Curtis, and P.P. PAsteris. 2008. Physiographically sensitive mapping of climatological temperature and precipitation across the conterminous United States. International Journal of Climatology 28:2031-2064.

DE'Ath, G., AND K.E. FAbRicius. 2000. Classification and regression trees: a powerful yet simple technique for ecological data analysis. Ecology 81:3178-3192.

Delaloye, R., and C. Lambiel. 2005. Evidence of winter ascending air circulation throughout talus slopes and rock glaciers situated in the lower belt of alpine discontinuous permafrost (Swiss Alps). Norsk Geografisk Tidsskrift - Norwegian Journal of Geography 59:194-203.

Erb, L.P., C. RaY, and R. Guralnick. 2011. On the generality of a climate-mediated shift in the distribution of the American pika (Ochotona princeps). Ecology 92:1730-1735.

Fu, P., AND P.M. Rich. 1999. Design and implementation of the Solar Analyst: an ArcView extension for modeling solar radiation at landscape scales. Proceedings of the Nineteenth Annual ESRI User Conference.

FU, P., AND P.M. RiCH. 2002. A geometric solar radiation model and its applications in agriculture and forestry. Proceedings of the Second International Conference on Geospatial Information in Agriculture and Forestry I-357-364.

Gude, M., S. Dietrich, R. Mäusbacher, C. Hauck, R. Molenda, V. RuZicKa, and M. ZaCharda. 2003. Probable occurrence of sporadic permafrost in non-alpine scree slopes in central Europe. Proceedings of the 8th International Conference on Permafrost, Zurich 2003:331-336.

Hafner, D.J., AND A.T. Smith. 2010. Revision of the subspecies of the American pika, Ochotona princeps (Lagomorpha: Ochotonidae). Journal of Mammalogy 91:401-417.

HaLL, E.R. 1946. Mammals of Nevada. University of Nevada Press, Las Vegas, NV.

Hall, L.E., A.D. Chalfoun, E.A. Beever, and A.E. LOOSEN. 2016. Microrefuges and the occurrence of thermal specialists: implications for wildlife persistence amidst changing temperatures. Climate Change Responses 3:8.

Harris, S.A., and D.E. Pederson. 1998. Thermal regimes beneath coarse blocky materials. Permafrost and Periglacial Processes 9:107-120.

Hobbs, R.J., D.N. Cole, L. Yung, E.S. Zavaleta, G.H. Aplet, F.S. Chapin, P.B. Landres, D.J. Parsons, N.L. Stephenson, P.S. White, ET AL. 2010. Guiding concepts for park and wilderness stewardship in an era of global environmental change. Frontiers in Ecology and the Environment 8:483-490.

Jeffress, M.R., T.J. Rodhouse, C. Ray, S. WolfF, and C.W. EPPS. 2013. The idiosyncrasies of place: geographic variation in the climate-distribution relationships of the American pika. Ecological Applications 23:864-878

Kreuzer, M.P., and N.J. HunTly. 2003. Habitat-specific demography: evidence for source-sink population structure in a mammal, the pika. Oecologia 134: 343-349.

Manis, G., J. Lowry, and R.D. Ramsey. 2001. Pre-classification: an ecologically predictive landform model. GAP Analysis Bulletin Volume 10. U.S. Geological Survey, Biological Resources Division. http://www .gap.uidaho.edu/Bulletins/10/preclassification.htm 
Martínez-Meyer, E., A.T. Peterson, and W.W. HarGROVE. 2004. Ecological niches as stable distributional constraints on mammal species, with implications for Pleistocene extinctions and climate change projections for biodiversity. Global Ecology and Biogeography 13:305-314.

MiLLAR, C.I. 2011. Influence of domestic livestock grazing on American pika (Ochotona princeps) haypiling behavior in the eastern Sierra Nevada and Great Basin. Western North American Naturalist 71: $425-430$.

Millar, C.I., K. Heckman, C. Swanston, K. Schmidt, R.D. Westfall, and D.L. Delany. 2014. Radiocarbon dating of American pika fecal pellets provides insights into population extirpations and climate refugia. Ecological Applications 24:1748-1768.

Millar, C.I., R.D. Westfall, and D.L. Delany. 2013. New records of marginal locations from American pika (Ochotona princeps) in the western Great Basin. Western North American Naturalist 73:457-476.

Millar, C.I., R.D. Westfall, and D.L. Delany. 2016. Thermal components of American pika habitat-how does a small lagomorph encounter climate? Arctic, Antarctic, and Alpine Research 48:327-343.

Morueta-Holme, N., C. FløjgaARd, and J. Svenning. 2010. Climate change risks and conservation implications for a threatened small-range mammal species. PLOS ONE. http://journals.plos.org/plosone/article ?id $=10.1371 /$ journal.pone. 0010360

Moyer-Horner, L., M.M. Smith, ANd J. Belt. 2012. Citizen science and observer variability during American pika surveys. Journal of Wildlife Management 76:1472-1479.

Parmesan, C. 2006. Ecological and evolutionary responses to recent climate change. Annual Review of Ecology, Evolution, and Systematics 37:637-669.

Ray, C., E.A. Beever, and T.J. Rodhouse. 2016. Distribution of a climate-sensitive species at an interior range margin. Ecosphere 7:e01379.

R Development Core Team. 2016. R: a language and environment for statistical computing. R Foundation for Statistical Computing, Vienna, Austria. https:// www.R-project.org

Regonda, S.K., B. Rajagopalan, M. Clark, and J. Pituick. 2005. Seasonal cycle shifts in hydroclimatology over the western United States. Journal of Climate 18:372-384.

Rodhouse, T.J., E.A. Beever, L.K. Garkett, K.M. Irvine, M.R. Jeffress, M. Munts, and C. Ray. 2010. Distribution of American pikas in a low-elevation lava landscape: conservation implications from the range periphery. Journal of Mammalogy 91:1287-1299.

SAWADA, Y., M. IshiKaWa, and Y. ONO. 2003. Thermal regime of sporadic permafrost in a block slope on Mt. Nishi-Nupukaushinupuri, Hokkaido Island, Northern Japan. Geomorphology 52:121-130.

Schwalm, D., C.W. Epps, T.J. Rodhouse, W.B. Monahan, J.A. Castillo, and M.R. Jeffresess. 2016. Habitat availability and gene flow influence diverging local population trajectories under scenarios of climate change: a place-based approach. Global Change Biology 22:1572-1584.

Shinderman, M. 2015. American pika in a low-elevation lava landscape: expanding the known distribution of a temperature-sensitive species. Ecology and Evolution 5:3666-3676.

Simpson, W.G. 2009. American pikas inhabit low-elevation sites outside the species' previously described bioclimatic envelope. Western North American Naturalist 69:243-250.

SмITH, A.T. 1974. Distribution and dispersal of pikas: influence of behavior and climate. Ecology 55:1368-1376.

Smith, A.T., J.D. NaGY, AND C.I. MilLaR. 2016. Behavioral ecology of American pikas (Ochotona princeps) at Mono Craters, California: living on the edge. Western North American Naturalist 76:459-484.

SMith, A.T., AND M.L. Weston. 1990. Ochotona princeps. Mammalian Species 352:1-8.

SteWART, J.A.E., AND D.H. Wright. 2012. Assessing persistence of the American pika at historic localities in California's northern Sierra Nevada. Wildlife Society Bulletin 36:759-764.

Thomas, C.D., E.J. Bodsworth, R.J. Wilson, A.D. Simmons, Z.G. Davies, M. Musche, and L. Conradt. 2001. Ecological and evolutionary processes at expanding range margins. Nature 411:577-581.

USGS Gap Analysis Program. 2013. Ochotona princeps. U.S. Geological Survey Gap Analysis Program Species Distribution Models.

VARnER, J., AND M.D. DEARING. 2014a. Dietary plasticity in pikas as a strategy for atypical resource landscapes. Journal of Mammalogy 95:72-81.

VARNER, J., AND M.D. DEARING. 2014b. The importance of biologically relevant microclimates in species distribution models. PLOS ONE 9(8):e104648.

Wildlife Action Plan Team. 2012. Nevada Wildlife Action Plan. Nevada Department of Wildlife, Reno, NV.

Wilkening, J.L., and C. RaY. 2016. Characterizing predictors of survival in the American pika (Ochotona princeps). Journal of Mammalogy 97:1366-1375.

Wilkening, J.L., C. Ray, E.A. Beever, and P.F. BrusSARD. 2011. Modeling contemporary range retraction in Great Basin pikas (Ochotona princeps) using data on microclimate and microhabitat. Quaternary International 27:1-12.

Wilkening, J.L., C. Ray, N. Ramsay, and K. Klingler. 2015. Alpine biodiversity and assisted migration: the case of the American pika (Ochotona princeps). Biodiversity 16:224-236.

ZaChaRdA, M., M. GUDE, AND V. RU゚ŽIČKa. 2007. Thermal regime of three low elevation scree slopes in central Europe. Permafrost and Periglacial Processes 18: 301-308.

Received 8 July 2016

Accepted 23 March 2017

Published online 19 July 2017 